Uniwersytet PrzyrodniczoHumanistyczny w Siedlcach

Siedlce University of Natural Sciences and Humanities

https://bazawiedzy.uph.edu.pl

\begin{tabular}{|l|l|}
\hline Publikacja / Publication & $\begin{array}{l}\text { Genome size of the European domestic goose (Anser anser domesticus), } \\
\text { Andraszek Katarzyna, Wójcik Ewa Agnieszka, Grużewska Agata Ewa, Smalec } \\
\text { Elżbieta Maria }\end{array}$ \\
\hline $\begin{array}{l}\text { Adres publikacji w Repozytorium } \\
\text { URL / Publication address in } \\
\text { Repository }\end{array}$ & https://bazawiedzy.uph.edu.pl/info/article/UPH88815671bf8044dd95e52d63501f9b1c/ \\
\hline $\begin{array}{l}\text { Data opublikowania w Repozytorium } \\
\text { / Deposited in Repository on }\end{array}$ & 22 paź 2021 \\
\hline Rodzaj licencji / Type of licence & Other open licence $\odot$ \\
\hline Cytuj tę wersję / Cite this version & $\begin{array}{l}\text { Andraszek Katarzyna, Wójcik Ewa Agnieszka, Grużewska Agata Ewa, Smalec } \\
\text { Elżbieta Maria: Genome size of the European domestic goose (Anser anser } \\
\text { domesticus), Canadian Journal of Animal Science, vol. 89, no. 4, 2009, pp. 449-455 }\end{array}$ \\
\hline
\end{tabular}




\title{
Genome size of the European domestic goose (Anser anser domesticus)
}

\author{
Katarzyna Andraszek ${ }^{1}$, Ewa Wójcik ${ }^{1}$, Agata Grużewska $^{2}$, and Elżbieta Smalec ${ }^{1}$ \\ ${ }^{1}$ Institute of Bioengineering and Animal Breeding, University of Podlasie, Prusa 14, 08-110 Siedlce, Poland; \\ and ${ }^{2}$ Department of Agricultural Experimentation, University of Podlasie, Prusa 14, 08-110 Siedlce, Poland \\ (e-mail: andrasz@ap.siedlce.pl). Received 8 December 2008, accepted 7 August 2009.
}

\begin{abstract}
Andraszek, K., Wójcik, E., Grużewska, A. and Smalec, E. 2009. Genome size of the European domestic goose (Anser anser domesticus). Can. J. Anim. Sci. 89: 449-455. This work is aimed at determining the C-DNA contained within the nuclei of different types of cells in the domestic goose Anser anser. Cells from the lungs, skin, pancreas, kidney, spleen, liver, heart, brain, blood, ovary and testicle were analysed. Cells from the blood, ovary and testicle were smeared onto microscopic glasses, whereas slides from the other organs and tissues were prepared using the paraffin technique. DNA content, as visualized by the Feulgen reaction using computerized image analysis, was examined in \pm 200 nuclei of every type of cell. Chicken erythrocytes were used as reference material. Different concentrations of chromatin within cell nuclei were observed, from small, dispersed clods to an entirely filled nucleus surface. It was stated that the average C-DNA content in the domestic European goose amounts to $1.306 \pm 0.327 \mathrm{pg}$, which gives goose DNA a length in base pair of $1.277 \times 10^{9} \pm$ $0.320 \times 10^{9}$ bp after adjustment. The correlation between nucleus size and the C-DNA content was positive and high. In all cell types it exceeded 0.6. The highest was observed in lung and ovary cells, the lowest in skin and the pancreas. The majority of all cells $(57.34 \%)$ contain DNA at the range between 1.0 to $1.5 \mathrm{pg}$, especially those from erythrocytes and the pancreas ( 82 and $76 \%$ respectively). Liver cells demonstrate a tendency toward an amount that is higher than $1.5 \%$ of the DNA (78.61\% cells). Heart cells reveal a tendency downward (98.99\% below $1.5 \mathrm{pg}$.). Less than 1.0 pg of DNA was observed in $17.13 \%$ of all examined cells.
\end{abstract}

Key words: Domestic goose, cell, cell nuclei, Feulgen reaction, genome size, DNA mass

Andraszek, K., Wójcik, E., Grużewska, A. et Smalec, E. 2009. Taille du génome de l'oie cendrée d'Europe (Anser anser domesticus). Can. J. Anim. Sci. 89: 449-455. Ce travail devait préciser la nature de l'ADN-C présent dans le noyau de diverses cellules de l'oie domestique (Anser anser). Les auteurs ont analysé les cellules des poumons, de l'épiderme, du pancréas, des reins, de la rate, du foie, du cæur, du cerveau, du sang, des ovaires et des testicules. Celle du sang, des ovaires et des testicules ont été examinées par frottis sur des lames de microscope, alors que celles des autres organes et tissus ont été préparées avec de la paraffine. La concentration d'ADN a été établie par la réaction de Feulgen suivie d'analyse de l'image sur ordinateur pour \pm 200 noyaux de chaque type de cellule. Les érythrocytes de poulet ont servi de point de référence. La concentration de chromatine varie dans le noyau, allant de petits amas dispersés à un noyau entièrement plein en surface. On estime que la teneur moyenne en $\mathrm{ADN}-\mathrm{C}$ se situe à $1,306 \pm 0,327 \mathrm{pg}$ chez l'oie, ce qui donne $1,277 \times 10^{9} \pm$ $0,320 \times 10^{9}$ paires de bases après correction. La taille du noyau et la concentration d'ADN-C présentent une forte corrélation positive. Cette corrélation dépasse 0,6 dans toutes les cellules. La plus forte corrélation survient dans les cellules des poumons et des ovaires, la plus faible ayant été relevée dans la peau et le pancréas. On trouve de 1,0 à 1,5 pg d'ADN dans la plupart des cellules $(57,34 \%)$, particulièrement les érythrocytes et les cellules pancréatiques $(82 \%$ et $76 \%$, respectivement). Les cellules du foie ont tendance à renfermer plus de $1,5 \%$ d'ADN (78,61\% des cellules). Celles du cæur, en revanche, affichent la tendance inverse (98,99\% contiennent moins de $1,5 \mathrm{pg}$ d'ADN). Enfin, on relève moins de $1,0 \mathrm{pg}$ d'ADN dans $17,13 \%$ des cellules examinées.

Mots clés: Oie domestique, cellule, noyau cellulaire, réaction de Feulgen, taille du génome, masse de l'ADN

The term "genome" is used to denote a complete set of chromosomes and all of the sequences located in them. As different cells of one and the same organism can have a different ploidy level, the size of a genome always refers to the haploid set of chromosomes. The size of a genome may also be expressed in terms of a physical measure that is a DNA mass, which is called C-DNA and expressed in picograms (pg). $\mathrm{C}$ refers to either "constant" or "characteristic".

Genome sizes of different organisms vary and range from about $10^{-3}$ to $10^{3} \mathrm{pg}$ (Gregory and Hebert 1999). However, the phylogenetic position of an organism does not constitute a basis for making inferences regarding its genome size. Genomes of organisms at the lowest stages of evolution, e.g., Amoeba dubia (700 pg), are exponentially larger than genomes of organisms at the top of the evolutionary ladder, e.g., Homo sapiens $(3.5 \mathrm{pg})$. This discrepancy between the level of evolutionary development and genome size is especially clear among animals, in which, unlike plants, there is no phenomenon of generative endopoliploidy, which results in an increase of the DNA content within the cell nucleus. The lack of correlation between progress in the evolution of organisms and their genome size is referred to as the $\mathrm{C}$-value 
paradox. This paradox remained a mystery until the sequencing of the human DNA molecule. It was found that functional protein-coding genes constitute barely a few percent of the genome and that increases in the genome size were not proportional to their rank on the phylogenetic ladder. This resulted in genome enrichment in non-coding sequences (Greilhuber et al. 1983; Gregory 2002a, 2003, 2005b).

A range of factors influence the results of C-DNA measurements. Determination of genome size in units of mass (pg) is carried out by utilizing biochemical reactions, densitometry, densitometric analysis of images, static fluorometry, flow cytometry and other methods (Prenna et al. 1974; Dewse and Potter 1975; Böcking et al. 1995; Hardie et al. 2002). An application of confocal microscopy in studies aimed at ascertaining genome size introduced a new variation factor, i.e., the extinction of fluorescent light during the analysis of preparations (Erlandsen and Rasch 1994). The values obtained that reflect the genome size of an organism are influenced by both the method of estimation and the tissue in which these measurements are made (Allison et al. 1981). Halle (1963) observed varied DNA content in different types of leukocytes stemming from one and the same individual. In the case of cells representing different tissues or organs, the estimated content is associated with different sizes of cells and cell nuclei as well as various degrees of chromatin packing (Hardie et al. 2002). DNA content in mitotically active cells may fluctuate from 2 to $4 \mathrm{C}$, according to the interphase stage and the degree of replication progress (Schulte and Wittekind 1990). What is more, the estimated C-DNA content may be influenced by other factors like preparation age or referential material.

A bird genome is approximately one-third the size of a human genome and is one of the smallest among vertebrates (Burt 2002; Gregory 2002a, 2007). The average size of a bird genome, expressed in terms of C-DNA, is $1.45 \mathrm{pg} \pm 0.01$ and ranges from $0.97 \mathrm{pg}$ in pheasant (Fascianus colchicus) to $2.16 \mathrm{pg}$ in ostrich (Strutio camelus). The approximate DNA content in the diploid nucleus of Gallus amounts to $2.5 \mathrm{pg}$ (Tiersch et al. 1989). This value, converted into the haploid one, is a reference point for similar studies carried out on other animal species.

At this point the genome size data base (Gregory 2005a) contains descriptions of genomes of 4890 organisms, including 3191 records of vertebrates, which are continuously increasing. The avian class, which encompasses over 10000 species, has 436 representatives in the data base. Only 26 records describe individuals from the family Anatidae, these include 3 individuals representing three goose species.

No systematic range ( $r=0.27$ to $r=0.6$ ) was found in birds when comparing genome size and karyotype size, which suggests that bird genome size has been evolving irrespective of the karyotype (Bachmann et al. 1972; Venturini et al. 1986). However, it has been observed that there is a positive association between bird genome size and erythrocyte size, and a negative correlation between genome size and the rate of a cell's metabolic changes. In spite of earlier assumptions, no correlations are found between bird genome size and the rate of development or longevity. What was confirmed was that the sizes of genomes of non-flying birds were far larger than those of flying birds. However, it is not clear whether avian genomes underwent shrinkage following metabolic changes connected with the development of the ability to fly, or if they had always been small (Vinogradov 1997; Hughes 1999; Gregory 2002a).

The application of modern technology makes possible the thorough and accurate examination the genome structure. However, despite enormous technological possibilities, there is still a lack of knowledge of the genomes of animals such as geese. Compared with animals that are economically utilized, there is insufficient knowledge of goose genetic material.

This fact necessitates these studies, which aim at describing the size of a domestic goose genome on the basis of C-DNA content in different types of cells.

\section{MATERIAL AND METHODS}

An experiment was undertaken on 1-yr-old birds of the Italian goose (strain W11). Material for the study was obtained during slaughter at a company in which every stage of processing was subject to veterinary control and met with the European Union requirements. Cell nuclei were isolated from erythrocytes and cells of selected domestic goose organs were examined. Samples of lung, skin, pancreas, kidney, spleen, liver, heart, brain and ovary were taken from one individual in addition to a peripheral blood sample. Additionally, a testicle sample was taken from the second individual. The estimated diploid number of chromosomes was $2 n=80$ for both birds. Preparations of ovary, testicle and blood, as well as a standard preparation of chicken blood, were prepared by the smear technique. Preparations from the remaining tissues were made by means of the paraffin technique. Gallus domesticus erythrocytes acted as a standard for C-DNA content, which was $1.25 \mathrm{pg}$. (Nakamura et al. 1990; Tiersch and Wachtel 1991).

The preparations were then subjected to the Feulgen reaction. Conditions of the reaction were adapted for densitometric examination using computerized image analysis, which was applied in order to estimate the animal genome sizes (Teichman et al. 1980; Greilhuber and Temsch 2001; Hardie et al. 2002). A measuring program Cytophotometer for Microscan was used to determine C-DNA values in cell nuclei. The initial material used for measurement consisted of images of histological preparations and their respective referential images generated by Microscan. Measurements included the testicle nucleus surface area and the integrated optical density. Integrated optical density for a stain rating scale of up to 256 of the system was calculated according to the following formula: 


$$
I O D=\sum_{i=1}^{n}-\log \left(\frac{I F_{i}}{I B_{i}}\right)
$$

where $n$ is the total number of pixels in a cell nucleus, $I F_{\mathrm{i}}$ is the intensity of the cell nucleus analyzed (in pixels), and $\mathrm{IB}_{\mathrm{i}}$ is the intensity of referential background (in pixels).

Nuclear DNA mass in picograms (pg) was converted by measuring referential mass on the basis of changes in optical density. Next, DNA mass was converted to DNA length, according to the formula proposed by
Dolezel et al. (2003) in which: base pairs (bp) number $=$ mass in $\mathrm{pg} \times 0.978 \times 10^{9}$. All of the cell types were characterized according to their C-DNA contents, nucleus surface areas and correlation coefficients between the C-DNA contents and cell nucleus surface areas. In total, measurements included 2201 cell nuclei from 195 to 205 from each cell type.

\section{RESULTS}

Fig. 1 is a compilation of microscopic images (b to l) of different goose cell types and chicken erythrocytes (a) with which goose cells are compared. The single cell

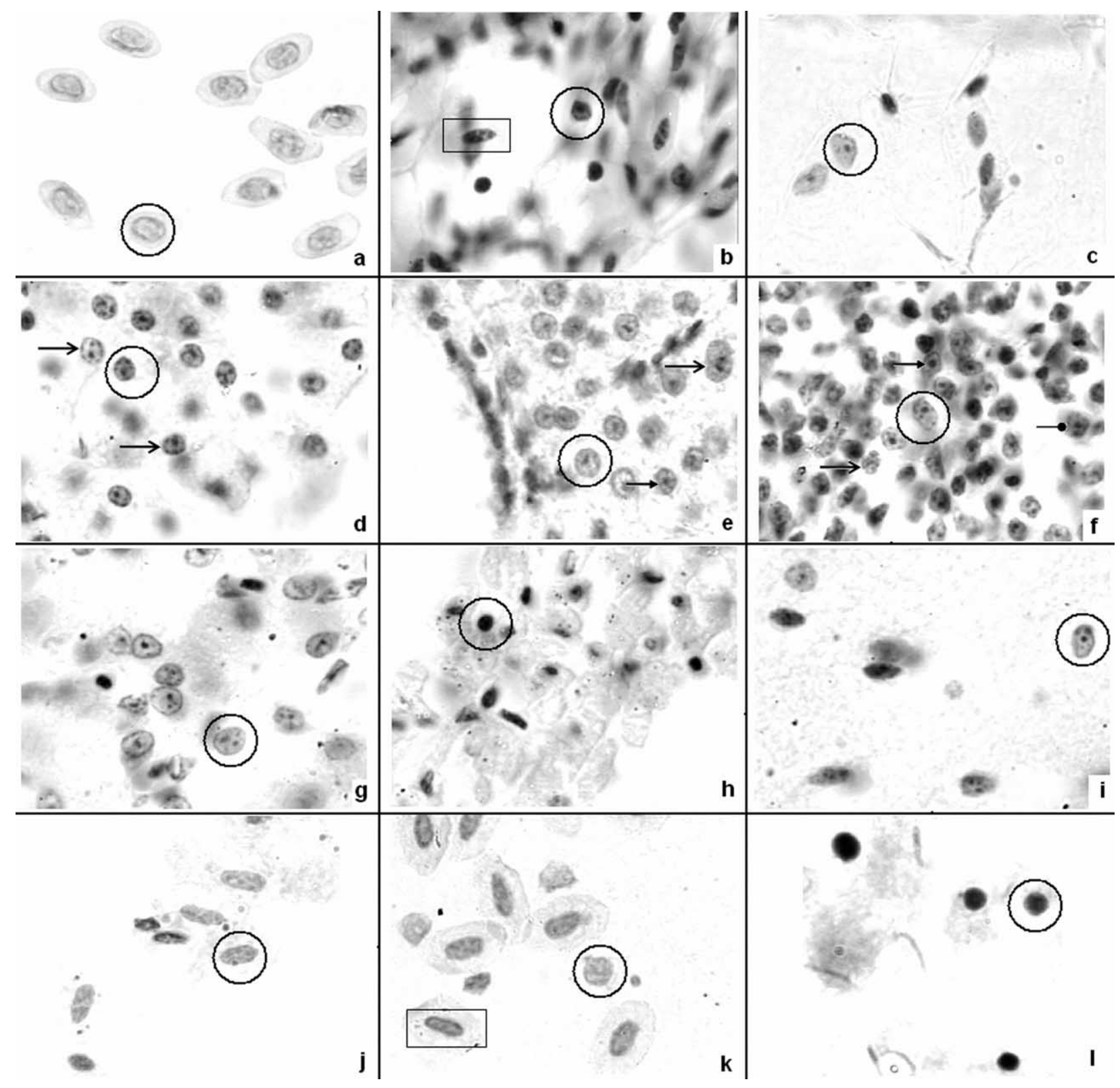

Fig. 1. Microscopic images of the analyzed cell types: a, chicken; b-1, goose. a, erythrocytes; b, lung; c, skin; d, pancreas; e, kidney; f, spleen; g, liver; h, heart; i, brain, j, blood (erythrocytes); k, ovary, 1, testes (marks described in text). 


\begin{tabular}{|c|c|c|c|c|c|}
\hline Cell types & Statistic & Cell nucleus surface area $(\mu \mathrm{m})$ & C-DNA (pg) & DNA (Gbp) & Correlation coefficient ${ }^{\mathbf{z}}$ \\
\hline & $\overline{\mathrm{x}} \pm \mathrm{SD}$ & $15987 \pm 3687$ & $1.334 \pm 0.320$ & $1.305 \pm 0.313$ & \\
\hline \multirow[t]{4}{*}{ Lung } & $\mathrm{V} \%$ & 23 & 24.00 & 24.00 & 0.909 \\
\hline & $\min$ & 9180 & 0.779 & 0.762 & \\
\hline & $\max$ & 26190 & 1.992 & 1.948 & \\
\hline & $\overline{\mathrm{x}} \pm \mathrm{SD}$ & $11892 \pm 1962$ & $1.192 \pm 0.200$ & $1.166 \pm 0.195$ & \\
\hline \multirow[t]{4}{*}{ Skin } & $\mathrm{V} \%$ & 16 & 16.74 & 16.74 & 0.601 \\
\hline & $\min$ & 8250 & 0.588 & 0.575 & \\
\hline & $\max$ & 18310 & 1.895 & 1.853 & \\
\hline & $\overline{\mathrm{x}}+\mathrm{SD}$ & $21316+3559$ & $1.332+0.242$ & $1.303+0.237$ & \\
\hline \multirow[t]{4}{*}{ Pancreas } & $\mathrm{V} \%$ & 17 & 18.19 & 18.19 & 0.636 \\
\hline & $\min$ & 10870 & 0.819 & 0.801 & \\
\hline & $\max$ & 29920 & 2.015 & 1.971 & \\
\hline & $\overline{\mathrm{x}} \pm \mathrm{SD}$ & $26346 \pm 5056$ & $1.335 \pm 0.263$ & $1.317 \pm 0.259$ & \\
\hline \multirow[t]{4}{*}{ Kidney } & $\mathrm{V} \%$ & -19 & 19.70 & 19.70 & 0.836 \\
\hline & $\min$ & 16010 & 0.755 & 0.746 & \\
\hline & $\max$ & 41060 & 1.972 & 1.946 & \\
\hline & $\overline{\mathrm{x}} \pm \mathrm{SD}$ & $21567 \pm 4803$ & $1.255 \pm 0.308$ & $1.226 \pm 0.299$ & \\
\hline \multirow[t]{4}{*}{ Spleen } & $\mathrm{V} \%$ & 22 & 24.36 & 24.36 & 0.881 \\
\hline & $\min$ & 13590 & 0.764 & 0.748 & \\
\hline & $\max$ & 37290 & 2.158 & 2.110 & \\
\hline & $\overline{\mathrm{x}} \pm \mathrm{SD}$ & $34758 \pm 6325$ & $1.715 \pm 0.258$ & $1.677 \pm 0.253$ & \\
\hline \multirow[t]{4}{*}{ Liver } & $\mathrm{V} \%$ & 18 & 15.07 & 15.07 & 0.831 \\
\hline & $\min$ & 17840 & 0.870 & 0.851 & \\
\hline & $\max$ & 46690 & 2.372 & 2.320 & \\
\hline & $\overline{\mathrm{x}}+\mathrm{SD}$ & $12417+3290$ & $1.014+0.222$ & $0.992+0.217$ & \\
\hline \multirow[t]{4}{*}{ Heart } & $\mathrm{V} \%$ & -26 & 21.86 & 21.86 & 0.869 \\
\hline & $\min$ & 6350 & 0.471 & 0.461 & \\
\hline & $\max$ & 20760 & 1.731 & 1.693 & \\
\hline & $\overline{\mathrm{x}}+\mathrm{SD}$ & $24459+5458$ & $1.468+0.290$ & $1.435+0.285$ & \\
\hline \multirow[t]{4}{*}{ Brain } & $\mathrm{V} \%$ & -22 & 19.85 & 19.85 & 0.872 \\
\hline & $\min$ & 13350 & 0.894 & 0.875 & \\
\hline & $\max$ & 38330 & 2.226 & 2.177 & \\
\hline & $\overline{\mathrm{x}} \pm \mathrm{SD}$ & $23199 \pm 3019$ & $1.207 \pm 0.188$ & $1.181 \pm 0.184$ & \\
\hline \multirow[t]{4}{*}{ Blood } & $\mathrm{V} \%$ & 13 & 15.55 & 15.55 & 0.857 \\
\hline & $\min$ & 17030 & 0.811 & 0.793 & \\
\hline & $\max$ & 29900 & 1.941 & 1.898 & \\
\hline & $\overline{\mathrm{x}} \pm \mathrm{SD}$ & $28737 \pm 7157$ & $1.438 \pm 0.353$ & $1.406 \pm 0.345$ & \\
\hline \multirow[t]{4}{*}{ Ovary } & $\mathrm{V} \%$ & 25 & 24.56 & 24.56 & 0.920 \\
\hline & $\min$ & 19000 & 0.901 & 0.881 & \\
\hline & $\max$ & 44270 & 2.256 & 2.207 & \\
\hline & $\overline{\mathrm{x}} \pm \mathrm{SD}$ & $23997 \pm 4320$ & $1.065 \pm 0.272$ & $1.042 \pm 0.266$ & \\
\hline \multirow[t]{4}{*}{ Testicle } & $\mathrm{V} \%$ & 18 & 25.53 & 25.53 & 0.768 \\
\hline & $\min$ & 19120 & 0.605 & 0.591 & \\
\hline & $\max$ & 38690 & 1.935 & 1.893 & \\
\hline & $\overline{\mathrm{x}} \pm \mathrm{SD}$ & $22339 \pm 9773$ & $1.306 \pm 0.327$ & $1.277 \pm 0.320$ & \\
\hline \multirow[t]{3}{*}{ Total } & $\mathrm{V} \%$ & -36 & 25.02 & 25.02 & 0.736 \\
\hline & $\min$ & 6350 & 0.471 & 0.460 & \\
\hline & $\max$ & 46690 & 2.372 & 2.320 & \\
\hline
\end{tabular}

${ }^{\mathrm{z}}$ Correlation coefficient between the C-DNA content and cell nucleus surface areas.

nucleus (as an exemplary) is circled. The same blood cells appear within analyzed tissues, which are shown in a rectangle. While the shape of cells is tissue specific, size and appearance of cell nuclei vary within every tissue. Cells that have chromatin concentrated in the centre of the nucleus are indicated with a closed arrow. Cells with a nucleus where chromatin is visible in the form of small granules (known as chromocentres) are indicated with an open arrow. Additionally, cell nuclei with a chromatin lump in the centre accompanied by small chromocentres in the proximity of the nuclear membrane are marked on photographs by pointed arrows. There are also instances in cells where chromatin occupies the entire nucleus area.

Table 1 presents results of measurements of nuclei in 11 evaluated cell types. The nucleus surface varies from 11892 to $34758 \mu \mathrm{m}$ with a coefficient of variation of 16 to 26. The adjusted amount of C-DNA in pg for all cell types is $1.306 \pm 0.327 \mathrm{pg}$, varying from $1.014 \mathrm{pg}$ in heart cells to 1.715 in liver cells. Relative to this adjustment is 
the quantity enunciated as the length of DNA in base pairs. On average it reached a length of $1.277 \times 109 \pm$ $0.320 \times 10^{9} \mathrm{bp}$. for domestic geese.

The correlation coefficient between C-DNA content and cell nucleus surface area (presented in Table 1) is high for all tissues, varying from 0.909 (lung) to 0.601 (skin).

Cells from different tissues and organs represent different metabolic rates according to the particular phase of cell cycle (meiosis/mitosis vs. replication phase) when the amount of DNA has been changed from 1 to 4C. The number of measurements (close to 200 per cell type), allows for the partitioning of cells according to the C-DNA content (Table 2). Four classes were arbitrarily chosen: nuclei with less than $1.0 \mathrm{pg}$ of DNA content, those with between 1.0 and $1.5 \mathrm{pg}$, those with between 1.51 and $2.0 \mathrm{pg}$ and those with more than $2.0 \mathrm{pg}$. Most of the cells $(57.34 \%)$ contain DNA ranging between 1.0 and $1.5 \mathrm{pg}$. Cells of erythrocytes and the pancreas contain mainly between 1.0 and $1.5 \mathrm{pg}$ of DNA (82 and $76 \%$, respectively). Liver cells demonstrate a tendency toward having more than $1.5 \mathrm{pg}$ of DNA (78.61\% cells) and heart cells reveal a tendency downward $(98.99 \%$ below $1.5 \mathrm{pg})$. Less $1.0 \mathrm{pg}$ of DNA is observed in $17.13 \%$ of all of the cells examined.

\section{DISCUSSION}

The size of a genome has a constant value and is species specific. Studies aimed at classifying genome size into physical units (pg) were initiated before the discovery of the DNA particle structure. Despite the fact that the so-called C-value paradox was solved following the understanding of the human genome, estimated C-DNA amounts are still problematic (Gregory 2002b; Vinogradov 2004). For this reason the comprehensive animal genome size data base (Gregory 2005a) presents selected methods, cell types and reference materials for every species.
According to Hardie et al. (2002), the choice of referential tissue may become an additional source of variation. In the present work chicken erythrocytes were chosen as a standard for goose C-DNA measurements. However, the estimation value may change when compared with the standard of other tissues. Vinogradov (1998) compared mouse liver cells with chicken liver cells or with chicken erythrocytes. The resulting difference was $0.22 \mathrm{pg}$. of DNA. Simultaneously, however, the genome size of Drosophila melanogaster was assessed on the basis of comparisons with chicken erythrocytes (Rasch et al. 1971) and concurs with data obtained after sequencing the genome of this organism (Adams et al. 2000). In the present study, the C-DNA value in goose blood erythrocyte cells is compared with chicken blood erythrocytes, and amounts to $1.207 \pm 0.188 \mathrm{pg}$.

The selection of the method of C-DNA content assessment in cells also influences the value of the estimated C-DNA content. In birds, over $38.18 \%$ of analyses presented have been conducted by the Feulgen densitometry method and $47.64 \%$ have been carried out in a flow cytometery (Gregory 2005a). The densitometry technique of Feulgen-stained preparations accompanied by computer image analysis is at present recognised as the least erroneous and is used in medical diagnostics (Bertino et al. 1994; Fischler et al. 1994). The data base (Gregory 2005a) contains, among others, descriptions of representatives of three goose species: Ross's goose (Anser rossi), C-DNA value $=1.08$ (Tiersch and Wachtel 1991), Cape barren goose (Cereopsis naovahollandie), CDNA value $=1.42 \mathrm{pg}$ (Venturini et al. 1986) and one goose of unknown origin with a mean C-value content of $1.08 \mathrm{pg}$. The C-DNA value in 11 cell types ranges from 0.06 to $5.70 \mathrm{pg}$ (Gregory 2002a; Nakamura et al. 1990).

C-DNA content described in the literature is most often characterized by a single individual (Wagenmann et al. 1981; Tiersch and Wachtel 1991; Gregory 2005a),

Table 2. The C-DNA content in domestic goose cells

\begin{tabular}{|c|c|c|c|c|c|c|c|c|c|}
\hline \multirow[b]{3}{*}{ Cell types } & \multirow[b]{3}{*}{ Number of cell } & \multicolumn{8}{|c|}{ C-DNA content of cells (pg) } \\
\hline & & \multicolumn{2}{|c|}{$<1.0$} & \multicolumn{2}{|c|}{$1.0-1.5$} & \multicolumn{2}{|c|}{$1.51-2.0$} & \multicolumn{2}{|c|}{$>2.0$} \\
\hline & & Number & $\%$ & Number & $\%$ & Number & $\%$ & Number & $\%$ \\
\hline Lung & 201 & 36 & 17.91 & 99 & 49.25 & 66 & 32.84 & - & 0 \\
\hline Skin & 195 & 23 & 11.79 & 159 & 81.54 & 13 & 6.67 & - & 0 \\
\hline Pancreas & 205 & 12 & 5.85 & 142 & 69.27 & 49 & 23.9 & 2 & 0.98 \\
\hline Kidney & 198 & 18 & 9.09 & 127 & 64.14 & 53 & 26.77 & - & 0 \\
\hline Spleen & 206 & 46 & 22.33 & 122 & 59.22 & 32 & 15.53 & 6 & 2.92 \\
\hline Liver & 201 & 3 & 1.49 & 40 & 19.9 & 133 & 66.17 & 25 & 12.44 \\
\hline Heart & 196 & 93 & 47.45 & 100 & 51.02 & 3 & 1.53 & - & 0 \\
\hline Brain & 202 & 3 & 1.48 & 121 & 59.9 & 66 & 32.67 & 12 & 5.95 \\
\hline Blood & 202 & 33 & 16.34 & 153 & 75.74 & 16 & 7.92 & - & 0 \\
\hline Ovary & 198 & 18 & 9.09 & 109 & 50.05 & 52 & 26.26 & 19 & 5.60 \\
\hline Testes & 197 & 92 & 46.7 & 90 & 45.68 & 15 & 6.62 & - & 0 \\
\hline Total & 2201 & 377 & 17.13 & 1262 & 57.34 & 498 & 22.63 & 64 & 2.9 \\
\hline
\end{tabular}


despite the recommendation of Gregory et al. (2007) who recommend five individuals.

Presented investigations cover 11 types of cells with \pm 200 measurements per type. Cells from solid tissues were prepared by the paraffin method; however, ovary cells, with a high degree of cytoplasm, are too large to observe at microscopic amplification. Testes contain different types of cells, such as Sertoli, leyding and spermatogenic cells. The smear technique provides better access to cell nuclei than the paraffin method.

Cells from different organs are characterized by their differing sizes, and it is interesting to note that cell nucleus size is closely associated with entire cell size (Gregory 2002a). The total cell nucleus area of goose cells reaches $22339 \mu \mathrm{m}$ from a group of 11 cells types and the correlation between them and their C-DNA content amounts to 0.736 , on average, with a high variation between cell types. The smallest correlation, of C-DNA value $=0.601$, is found within skin cells and the largest, $\mathrm{C}-\mathrm{DNA}=0.909$, in lung cells. Blood proves to be the easiest to measure, showing $1.207 \mathrm{pg}$ DNA. The correlation between the C-DNA content and cell nucleus area was $r=0.857$. Chromatin is visible under the light microscope in the form of small granules (chromocentres) against a homogenous background. In nuclei with greater DNA contents, chromatin is in the form of large chromocentres and occupies the whole nucleus area (Greilhuber et al. 1983; Bennett and Leitch 2005; Gregory 2003, 2005b). The level of the organization of the chromatin undoubtedly influences the value of the correlation coefficient.

Adams, M. D., Celniker, S. E., Holt, R. A., Evans, C. A., Gocayne, J. D., Amanatides, P. G., Scherer, S. E., Li, P. W., Hoskins, R. A. and Galle, R. F. 2000. The genome sequence of Drosophila melanogaster. Science 287: 2185-2195.

Allison, D. C., Ridolpho, P. F., Rasch, E. M., Rasch, R. W. and Johnson, T. S. 1981. Increased accuracy of absorption cytophotometric DNA values by control of stain intensity. J. Histochem. Cytochem. 29: 1219-1228.

Bachmann, K., Harrington, B. A. and Craig, J. P. 1972. Genome size in birds. Chromosoma 37: 405-416.

Bennett M. D. and Leitch, I. J. 2005. Genome size evolution in plants. Pages 89-162 in T.. Gregory, ed. The evolution of the genome. Elsevier, San Diego, CA.

Bertino, B., Knape, W. A. Pytlinska, M. Strauss, K. and Hammou, J. C. 1994. A comparative study of DNA content as measured by flow cytometry and image analysis in 1864 specimens. Anal. Cell. Pathol. 6: 377-394.

Böcking, A., Giroud, F. and Reith, A. 1995. Consensus report of the ES-ACP task force on standardization of diagnostic DNA image cytometry. Anal. Cell. Pathol. 8: 67-74.

Burt, D. W. 2002. Origin and evolution of avian microchromosomes. Cytogenet. Genome Res. 96: 97-112.

Dewse, C. D. and Potter, C. G. 1975. Influence of light and mounting medium on the fading of Feulgen stain. Stain Technol. 50: 301-306.

Dolezel, J., Bartos, J., Voglmayr, H. and Greilhuber, J. 2003. Nuclear DNA content and genome size of trout and human. Cytometry 51: 127-128.
Erlandsen, S. L. and Rasch, E. M. 1994. The DNA content of trophozoites and cysts of Giardia lamblia by microdensitometric quantitation of Feulgen staining and examination by laser scanning confocal microscopy. J. Histochem. Cytochem. 42: 1413-1416.

Fischler, D. F., Wongbunnate, S., Johnston, D. A. and Katz, R. L. 1994. DNA content by image analysis: an accurate discriminator of malignancy in pericardial effusions. Anal. Quant. Cytol. Histol. 16: 167- 173.

Greilhuber, J. and Temsch, E. M. 2001. Feulgen densitometry: some observations relevant to best practice in quantitative nuclear DNA content determination. Acta Bot. Croat. 60: 285-298.

Greilhuber, J., Volleth, M. and Loidl, J. 1983. Genome size of man and animals relative to the plant Allium cepa. Can. J. Genet. Cytol. 25: 554-560.

Gregory, T. R. 2001. The bigger the C-value, the larger the cell: genome size and red blood cell size in vertebrates. Blood Cells Mol. Dis. 27: 830-843.

Gregory, T. R. 2002a. A bird's-eye view of the C-value enigma: genome size, cell size, and metabolic rate in the class Aves. Int. J. Org. Ewol. 56: 121-130.

Gregory, T. R. 2002b. Genome size and developmental parameters in the homeothermic vertebrates. Genome 45: 833-838.

Gregory, T. R. 2003. The C-value enigma in plants and animals: a review of parallels and an appeal for partnership. Ann. Bot. 95: 133-146.

Gregory, T. R. 2005a. Animal genome size database. [Online] Available: http:/www.genomesize.com.

Gregory, T. R. 2005b. Synergy between sequence and size in large-scale genomics. Nat. Rev. Genet. 6: 699-708.

Gregory, T. R. and Hebert, P. D. N. 1999. The modulation of DNA content: proximate causes and ultimate consequences. Genome Res. 9: 317-324.

Gregory, T. R., Nicol, J. A., Tamm, H., Kullman, B., Kullman, K., Leitch, I. J., Murray, B. G., Kapraun, D. F., Greilhuber, J. and Bennett, M. D. 2007. Eukaryotic genome size databases. Nucleic Acids Res. 35: D5-D12.

Griffin, D. K., Robertson, L. B., Tempest, H. G. and Skinner, B. M. 2007. The evolution of the avian genome as revealed by comparative molecular cytogenetics. Cytogenet. Genome Res. 117: 64-77.

Hale, A. J. 1963. The leucocyte as a possible exception to the theory of deoxyribonucleic acid constancy. J. Pathol. Bacteriol. 85: $311-326$.

Hardie, D. C., Gregory, T. R. and Hebert, P. D. N. 2002. From pixels to picograms: a beginners' guide to genome quantification by Feulgen image analysis densitometry. J. Histochem. Cytochem. 50: 735-749.

Hughes, A. L. 1999. Adaptive and characteristics of genome. Pages 180-222 in Adaptive evolution of genes and genomes. Oxford University Press, Oxford, UK.

Nakamura, D., Tiersch, T. R., Douglass, M. and Chandler, R. W. 1990. Rapid identification of sex in birds by flow cytometry. Cytogenet. Cell Genet. 53: 201-205.

Prenna, G., Leiva, S. and Mazzini, G. 1974. Quantitation of DNA by cytofluorometry of the conventional Feulgen reaction. Histochem. J. 6: 467-489.

Rasch, E. M., Barr, H. J. and Rasch, R. W. 1971. The DNA content of sperm of Drosophila melanogaster. Chromosoma 33: $1-18$. 
Schulte, E. K. W. and Wittekind, D. H. 1990. Standardization of the Feulgen reaction: the influence of chromatin condensation on the kinetics of acid hydrolysis. Anal. Cell. Pathol. 2: $149-157$.

Teichman, J. S., Krick, T. P. and Nettleton, G. S. 1980. Effects of different fuchsin analogs on the Feulgen reaction. J. Histochem. Cytochem. 28: 1062-1066.

Tiersch, T. R. and Wachtel, S. S. 1991. On the evolution of genome size of birds. J. Hered. 82: 363-368.

Tiersch, T. R., Chandler, R. W., Wachtel, S. S. and Elias, S. 1989. Reference standards for flow cytometry and application in comparative studies of nuclear DNA content. Cytometry 10: 706-710.

Venturini, G., D’ambrogi, R. and Capannae, E. 1986. Size and structure of the bird genome. I. DNA content of 48 species of Neognathae. Comp. Biochem. Physiol. 85: 61-65.
Vinogradov, A. E. 1997. Nucleotypic effect in homeotherms: body-mass independent metabolic rate of passerine birds is related to genome size. Evolution 51: 220-225.

Vinogradov, A. E. 1998. Genome size and GC-percent in vertebrates as determined by flow cytometry: the triangular relationship. Cytometry 31: 100-109.

Vinogradov, A. E. 2004. Evolution of genome size: multilevel selection, mutation bias or dynamical chaos? Curr. Opin. Genet. Dev. 14: 620-626.

Wagenmann, M., Epplen, J., Bachmann, K., Engel, W. and Schmidke, J. 1981. DNA sequence organisation in relation to genome size in birds. Experientia 37: 1274-1276. 